\title{
Aplikasi POC (Pupuk Organik Cair) Pada Persiapan Kolam Pembesaran Budidaya Udang Vannamei (Litopenaeus vannamei) Terhadap Pertumbuhan, Tingkat Kelangsungan Hidup, Rasio Konversi Pakan, dan Efisiensi Pemanfaatan Pakan
}

\section{Application of POC (Liquid Organic Fertilizer) in the Pond Preparation of Growing Vannamei Shrimp (Litopenaeus vannamei) Farming on Growth, Survival Rate, Feed Conversion Ratio, and Feed Utilization Efficiency.}

\author{
Nadya Rahadini ${ }^{1}$, Nina Nurmalia Dewi ${ }^{2}$ \\ ${ }^{1}$ Program Studi Akuakutur Fakultas Perikanan dan Kelautan Universitas Airlangga Surabaya. \\ ${ }^{2}$ Departemen Manajemen Kesehatan Ikan dan Budidaya Perairan, Fakultas Perikanan dan \\ Kelautan, Universitas Airlangga, Surabaya \\ *Corresponding author: ninanurmaliadewi@fpk.unair.ac.id
}

Submitted: 27 July 2021 Revised: 04 October 2021 Accepted: 18 October 2021 Publish: 30 October 2021

\begin{abstract}
Abstrak
Udang vannamei (Litopenaeus vannamei) merupakan salah satu komoditas yang bernilai tinggi. Budidaya udang vannamei saat ini mayoritas menggunakan sistem budidaya intensif yang dapat mengakibatkan masalah lingkungan air budidaya kolam itu sendiri seperti limbah organik yang dihasilkan. Tujuan dari penelitian ini adalah untuk mengetahui aplikasi POC (Pupuk Organik Cair) pada persiapan kolam pembesaran budidaya udang vannamei terhadap pertumbuhan, rasio konversi pakan, efisiensi pemanfaatan pakan, dan tingkat kelangsungan hidup udang vannamei. Penelitian ini dilaksanakan di Instalasi Budidaya Air Payau Prigi, Trenggalek, Provinsi Jawa Timur pada Desember 2019 - Januari 2020. Metode penelitian menggunakan deskriptif dengan pengambilan data meliputi data primer dan data sekunder. Hasil yang didapat menunjukkan bahwa udang mengalami pertumbuhan sebesar 1,67-4,33 gram/hari dan selalu mengalami kenaikan. Nilai FCR yaitu 1,6 dan EPP 62,5\%. SR sebesar $51,3 \%$. Rentang suhu selama penelitian berkisar $29^{\circ} \mathrm{C}-30,5^{\circ} \mathrm{C}$ sedangkan untuk pH berkisar antara 5,4-8, rata-rata nilai DO yaitu 4,86 mg/L, dan untuk salinitas berkisar antara 13-29 ppt. Keyword : pertumbuhan, kualitas air, tingkat kelangsungan hidup, pupuk organik cair.

\footnotetext{
Abstract

Vannamei shrimp (Litopenaeus vannamei) is one of the most valuable promising commodities. Nowadays, vaname shrimp cultivation usually uses an intensive system which can cause environmental problems such as the organic waste generated. The purpose of this study was to determine the application of POC (Liquid Organic Fertilizer) in the preparation of growing vannamei shrimp farming on growth, feed conversion ratio, feed utilization efficiency, and survival rate of vannamei shrimp. This research was conducted at the Prigi Brackish Water Cultivation Installation, Trenggalek, East Java Province in December 2019 - January 2020. The method in this research used descriptive method with data collection including primary data and secondary data. The results obtained indicate that the shrimp has a growth of 1.67-4.33 grams / day and always increases. The FCR values were 1.6 and the EPP was $62.5 \%$. The survival rate was $51.3 \%$. The temperature range during the study ranged from $29^{\circ} \mathrm{C}-30.5^{\circ} \mathrm{C}$ while for $\mathrm{pH}$ ranged from 5.4-8, the average DO value was $4.86 \mathrm{mg} / \mathrm{L}$, and for salinity it ranged from 13-29 ppt. Keyword : growth, water quality, survival rate, liquid organic fertilizer
} 


\section{PENDAHULUAN}

Udang vannamei merupakan salah satu jenis udang yang sering di budidayakan. Udang vannamei memiliki prospek dan profit yang menjanjikan (Babu dkk., 2014). Udang vannamei (Litopenaeus vannamei) merupakan udang asli perairan Amerika Latin yang masuk ke dalam Famili Penaidae. Udang vannamei memiliki laju pertumbuhan yang relatif cepat serta kemampuan adaptasi yang relatif tinggi terhadap perubahan lingkungan seperti perubahan suhu dan salinitas (Adiwijaya dkk., 2003). Haliman dan Adijaya (2005) menjelaskan bahwa udang vaname memiliki tubuh berbuku-buku dan memiliki kebiasaan berganti kulit luar (eksoskleton) secara periodik 8 (moulting) setiap kali tubuhnya membesar atau mengalami pertumbuhan, setelah itu kulit akan mengeras kembali.

Udang vannamei memiliki tubuh yang berwarna putih, oleh karena itu sering disebut juga sebagai udang putih. Budidaya udang vannamei saat ini biasa menggunakan sistem intensif yang mana dapat mengakibatkan masalah lingkungan air budidaya kolam itu sendiri seperti limbah organik yang dihasilkan. Limbah organik yang ada nantinya dapat menyebabkan menurunnya kualitas air selama masa pemeliharaan dan persiapan kolam. Padat tebar yang tinggi dan pemberian pakan yang banyak juga dapat menurunkan kondisi kualitas air. Hal ini diakibatkan adanya akumulasi bahan organik, karena udang menyerap protein pakan sekitar 16.3 - $40.87 \%$ dan sisanya dibuang dalam bentuk ekskresi residu pakan, serta feses (Yuniasari, 2009).

Upaya mengatasi permasalahan utama yakni menggunakan POC. POC (Pupuk Organik Cair) terdiri dari molase untuk meningkatkan aktifitas bakteri yang menguntungkan di dalam tambak udang vaname (Hari dkk., 2004)., starter (bionutren, biolizer, hormonik), SP-36, ZA g, susu skim sebagai sumber protein untuk meningkatkan asam amino dan kalsium (Setya, 2012), ragi tape, yakult, dan serbuk herbal. POC mengandung bakteri positif dalam jumlah banyak yang mampu menekan populasi plankton dan juga sebagai penstabil kualitas air seperti DO dalam rentang yang optimal (Arelano dkk., 2002). Berdasarkan latar belakang diatas maka tujuan dari penelitian ini adalah untuk mengetahui pengaruh pemberian POC (Pupuk Organik Cair) pada persiapan kolam pembesaran budidaya udang vannamei terhadap pertumbuhan, tingkat kelangsungan hidup, rasio konversi pakan, dan efisiensi pakan.

\section{METODE PENELITIAN}

Waktu dan tempat penelitian

Penelitian ini dilaksanakan di Instalasi Budidaya Air Payau Prigi (IBAP-Prigi) Prigi, Trenggalek pada bulan Desember 2019 - Januari 2020.

\section{Alat dan bahan}

Penelitian ini dilakukan pada kolam budidaya dengan dimensi luas $6,8 \mathrm{~m}^{2}$ dengan ketinggian air 1,5 $\mathrm{m}$, benur yang diaplikasikan yakni PL 8 (post larvae) dengan padat tebar 470 ekor/m². Selain itu, alat pengukuran kualitas air seperti; DO meter, $\mathrm{pH}$ meter, refraktometer, timbangan digital, timbangan pakan, mesin pengaduk, mesin diesel, anco, timba cat ukuran $25 \mathrm{~kg}$ digunakan untuk 
pengukuran secara in situ maupun ex situ. Selanjutnya, bahan seperti; POC (molase, starter (bionutren, biolizer, hormonik), SP36, ZA g, susu skim ragi tape, yakult, dan serbuk herbal) merupakan bahan yang diaplikasikan selama budidaya.

\section{Tahapan penelitian}

Tahap pertama pada penelitian ini yaitu persiapan kolam dengan pembersihan kolam dengan cara menggosok dinding dan dasar kolam dan menyemprotkan air tawar menggunakan selang. Selanjutnya, pengeringan kolam dilakukan selama 1 hari dan dilanjutkan pengapuran dengan kapur tohor $(\mathrm{CaO})$ dosis 30 ppm untuk kolam dengan luas $500 \mathrm{~m}^{2}$. Selanjutnya dilakukan pengsian air, dengan perbandingan air laut dan air tawar 3:1 hingga mencapai salinitas 22 - 25 ppt dan diaerasi. Tahap kedua yakni aplikasi POC (Pupuk Organik Cair) pada budidaya udang vannamei (Litopenaeus vannamei) yang diberikan setiap hari selama 7 hari sebanyak 0,6 liter/kolam. Setelah kolam siap digunakan, benih ditebar pada pukul 02.00 WIB dengan proses aklimatisasi menggunakan kantong plastik yang berisi benur dan menambahkan bionutren sebanyak $1 \mathrm{~mL}$ selama 1 - 3 menit. Selanjutnya kantong plastik dimiringkan dan benih dibiarkan berenang keluar dari wadah dengan sendirinya. Selama pemeliharaan udang vaname, pakan yang diberikan berupa pakan udang dengan merk dagang Evergreen. Pemberian pakan dilakukan dari pukul 05.00 sampai dengan pukul 24.00. Pemberian pakan dilakukan dengan cara ad libitum melalui kontrol anco. Pengukuran kualitas air meliputi suhu, salinitas, $\mathrm{pH}$ dan DO. Pengukuran suhu dilakukan sebanyak tiga kali sehari, pengukuran $\mathrm{pH}$ dan salinitas dilakukan sebanyak dua kali sehari, sedangkan pengukuran DO dilakukan selama tiga hari sekali. Kegiatan sampling berat udang dilakukan pada sampel udang sebanyak 20 ekor yang diukur seminggu sekali.

Parameter yang diamati

Pada penelitian ini terdiri dari parameter yang diamati terdiri dari parameter utama yang dihitung berdasarkan; tingkat kelangsungan hidup (Haliman dan Adiwijaya, 2005), laju pertumbuhan, rasio konversi pakan (Supono dkk., 2014), dan efisiensi pemberian pakan (Arsad dkk., 2017). Selanjutnya, parameter pendukung seperti suhu, salinitas, $\mathrm{pH}$, dan DO dilakukan secara periodik selama penelitian.

Average Daily Growth (ADG), dapat dihitung dengan rumus:

$$
\text { ADG }=\frac{\text { ABW II (gr) }- \text { ABW I (gr) }}{\text { T(hari })}
$$

Keterangan:

$$
\begin{aligned}
& \text { ABW I = Rataan berat awal (gram) } \\
& \text { ABW II = Rataan berat akhir (gram) } \\
& \text { T = Lama waktu pemeliharaan (hari) }
\end{aligned}
$$

Tingkat Kelangsungan Hidup (SR), dapat dihitung dengan rumus:

$\mathrm{SR}=\frac{\mathrm{Nt}}{\mathrm{No}} \times 100 \%$

Keterangan :

No = Jumlah udang awal pemeliharaan

$\mathrm{Nt}=$ Jumlah udang akhir pemeliharaan

Rasio konversi pakan (FCR), dapat 
dihitung dengan rumus:

FCR $=\frac{\mathbf{F}}{\text { Biomass }}$

Keterangan :

$\mathrm{F}=$ Jumlah pakan $(\mathrm{gr})$

Biomassa $=$ Biomassa udang

Efisiensi Pemberian pakan (EPP), dapat dihitung dengan rumus:

$\mathrm{EPP}=\frac{1}{\mathrm{FCR}} \times 100 \%$

\section{Analisis data}

Data dianalisis secara deskriptif dengan menghubungkan hasil perhitungan dan menarik kesimpulan dengan referensi yang relevan dan terbarukan.

\section{HASIL DAN PEMBAHASAN}

Berdasarkan hasil yang didapat pada penelitian ini, nilai SR didapat sebesar 51,3\% sehingga termasuk dalam nilai SR yang rendah. Nilai tersebut termasuk dalam angka yang rendah dibandingkan penelitian Nunes dan Neto (2011) dimana angka kelulushidupan udang vaname mencapai $81,4 \%$. Tingkat SR tersebut dipengaruhi oleh kualitas benih udang yang bersifat Specific Pathogen Free (SPF), yaitu benih yang bebas dari beberapa jenis patogen tertentu seperti White Feses Disease (WFD), Infectious Myonecrosis Virus (IMNV), dan White Spot Syndrome Virus (WSSV) serta kemampuannya memanfaatkan kolom air sebagai media hidup. Selain itu, rendahnya nilai SR dapat diindikasikan disebabkan oleh tingginya padat tebar benih udang. Menurut Rakhfid et al. (2017) nilai tingkat SR yang rendah pada padat tebar yang lebih tinggi diduga disebabkan oleh ruang gerak udang semakin sempit dan tingginya persaingan mendapatkan pakan. Penelitian ini memiliki padat tebar tiap kolam yakni 470 ekor $/ \mathrm{m}^{2}$ sedangkan pada penelitian Nunes dan Neto (2011) padat tiap kolam hanya 100 ekor/m². Hal ini menyebabkan udang menjadi lebih agresif sehingga menimbulkan stress pada udang yang memicu sifat kanibalisme antar individu, sehingga tingkat kematian meningkat. Selain stress, sifat kanibalisme pada udang dapat terjadi akibat proses moulting yang tidak bersamaan diantara udang yang satu dengan udang yang lainnya.

Tabel 1. Hasil perhitungan analisis budidaya dan kualitas air pada budidaya udang vannamei (Litopenaeus vanamei).

\begin{tabular}{rlll}
\hline No. & Parameter & Nilai & Satuan \\
\hline \multicolumn{2}{l}{ Parameter budidaya } & & \\
1 & ADG & $1,67-4,33$ & Gram/hari \\
2 & SR & 51,3 & $\%$ \\
3 & FCR & 1,6 & $\%$ \\
4 & EPP & 62,5 & $\%$ \\
Parameter kualitas air & & \\
1 & Salinitas & $13-29$ & $\mathrm{ppt}$ \\
2 & DO & 4,86 & $\mathrm{mg} / \mathrm{L}$ \\
3 & Suhu & $29-30,30,5$ & ${ }^{\circ} \mathrm{C}$ \\
4 & pH & $6,4-8$ & - \\
\hline
\end{tabular}


Pertumbuhan sebesar 1,67 - 4,33 gram/hari. Hal ini lebih tinggi dibandingkan penelitiannya Anwar et al. (2016) yang meneliti laju pertumbuhan udang vannamei dengan probiotik memiliki nilai terbaik yaitu $1,41 \pm 0,08$ gram/hari. Menurut Effendie (1997), pertumbuhan disebabkan oleh beberapa faktor salah satunya adalah pasokan energi dari pakan. Kelebihan dari energi yang dibutuhkan untuk pemeliharaan dan aktifitas tubuh dimanfaatkan untuk pertumbuhan. FCR pada penelitian ini yaitu 1,6 dan nilai EPP sebesar 62,5\% yang mana termasuk pada nilai yang baik. Arsad et al., (2017) menyatakan bahwa pada umumnya nilai FCR pada tambak udang vaname berkisar 1.4-1.8. Sehingga, nilai FCR pada pembesaran udang vaname dalam ruang tertutup berada pada kisaran normal. Nilai efisiensi pemberian pakan pada penelitian ini dikatakan baik karena lebih dari 50\%. Selain itu hasil pada penelitian ini juga lebih tingi dibandingkan penelitian Anwar et al. (2016) dengan nilai Epp tertinggi udang vaname sebesar $48,80 \quad \% \quad \pm 1,23$. Menurut Hariyadi et al. (2005), semakin tinggi nilai efisiensi pakan maka respon organisme budidaya terhadap pakan tersebut semakin baik yang ditunjukkan dengan pertumbuhan ikan yang cepat. Hasil data kualitas air didapat rentang suhu normal yakni $29-30,5^{\circ} \mathrm{C}$. Suhu air sangat berpengaruh terhadap metabolisme dan pertumbuhan organisme. Suhu juga mempengaruhi aktifitas fotosintesis serta kelarutan partikel-partikel yang ada di dalamnya dan sifat-sifat fisik, kimia dan biologi juga sangat berpengaruh pada suhu yang dapat mempengaruhi pada fisilogis kehidupan organisme budidaya, apabila kenaikan suhu mencapai pada batas-batas tertentu akan meningkatkan laju pertumbuhan udang (Andi, 2017).

Pertumbuhan udang vannamei yang optimum berkisar antara $26-32^{\circ} \mathrm{C}$. Kandungan oksigen terlarut pada seluruh kolam berada pada kisaran optimal, yaitu sebesar 4,86 mg/L. Nilai tersebut berada pada kisaran yang baik untuk budidaya udang vannamei. Menurut Arsad dkk., (2017) oksigen terlarut dibawah $3 \mathrm{mg} / \mathrm{L}$ akan menyebabkan udang stress dan mengalami kematian. Untuk nilai $\mathrm{pH}$, secara umum masih berada pada nilai standar, walaupun terdapat salah satu pengukuran terdapat nilai $\mathrm{pH} \quad 6,4$. Standar nilai $\mathrm{pH}$ yang ditetapkan pada IBAP Prigi yakni antara 7,0 - 8,0. Menurut Dede (2014) standar ambang batas nilai $\mathrm{pH}$ normal yaitu 7 - 8,5. Apabila terjadi penurunan nilai $\mathrm{pH}$ maka dilakukan pemberian kapur dolomit sebanyak $3 \mathrm{~kg}$ untuk 18 petak kolam di malam hari. Nilai salinitas terlihat naik turun berkisar 13-29 ppt, hal ini dikarenakan adanya masalah input air tawar dan laut. Nilai salinitas pada penelitian ini, terdapat nilai yang berada diluar standar untuk pemeliharaan udang vannamei. Salinitas yang tingi dapat disebabkan karena adanya penguapan air tambak sehingga kandungan air garam meningkat. Nilai kualitas air yang berada di luar standarnya menjadi salah satu indikasi yang berpengaruh terhadap pertumbuhan dan tingkat kelangsungan 
hidup udang vannamei (Purnamasari dkk., 2017).

\section{KESIMPULAN}

Pupuk Organik Cair pada persiapan pembesaran budidaya udang vannamei dapat memperbaiki laju pertumbuhan, rasio konversi pakan, dan efisiensi pemberian pakan. Hasil yang didapat menunjukkan bahwa udang mengalami pertumbuhan sebesar 1,674,33 gram/hari dan selalu mengalami kenaikan. Nilai FCR yaitu 1,6 dan EPP $62,5 \%$. SR sebesar 51,3\%. Namun aplikasi POC ini belum memberikan nilai tingkat kelangsungan hidup yang optimum.

\section{Ucapan Terima Kasih}

Terimakasih kepada Instalasi Budidaya Air Payau Prigi yang telah mengizinkan pelaksanaan penelitian ini dan saya mengucapkan terimakasih banyak kepada ibu Nina Nurmalia Dewi selaku dosen pembimbing saya yang telah memberikan arahan, petunjuk, dan bimbingan sejak awal hingga akhir penulisan.

\section{DAFTAR PUSTAKA}

Adiwijaya, D., Sapto, P.R., Sutikno, E., Sugeng, \& Subiyanto. 2003. Budidaya Udang Vaname (Litopenaeus vannamei) Sistem Tertutup yang Ramah Lingkungan. Departemen Kelautan dan Perikanan, Balai Besar Pengembangan Budidaya Air Payau, Jepara, 29 halaman.

Andi, S. dan Septiningsih, E. 2017. Variasi Waktu Kualitas Air pada Tambak Budidaya Udang dengan Teknologi Integrated Multitrophic Aquaculture (IMTA) Di Mamuju Sulawesi Barat. Jurnal Ilmu Alam dan Lingkungan, 8 (16) : 52-57.

Anwar, S., Arief, M., dan Agustono. 2016. Pengaruh pemberian probiotik komersial pada pakan terhadap laju pertumbuhan dan efisiensi pakan udang vaname (Litopenaeus vannamei). Journal of Aquaculture and Fish Health, 5 (2), 1-6.

Arellan`o C.F. \& Olmos S.J. (2002) Thermostablea-1,4-anda-1,6-glucosidase enzymes fromBacillussp. iso-lated from a marine environment.World Journal of Microbiology and Biotechnology18, 791-795.

Arsad, Sulastri., Afandy, Ahmad., Purwandhi, Atika. 2017. Studi Kegiatan Pembesaran Udang Vaname (Litopenaeus vannamei) dengan Penerapan Sistem Pemeliharaan Berbeda. Jurnal Ilmiah Perikanan dan Kelautan, 9 (1), 1-14.

Babu, D., Ravuru, J.N. Mude. 2014. Effect of Density on Growth and Production of Litopenaeus vannamei of Brackish Water Culture System in Summer Season with Artificial Diet in Prakasam District, India. American.

Dede, H., Aryawati, R dan Diansyah, G. 2014. Evaluasi Tingkat Kesesuaian Kualitas Air Tambak Udang Berdasarkan Produktivitas Primer PT. Tirta Bumi Nirbaya Teluk Hurun Lampung Selatan (Studi Kasus). Science Diver. Maspari Journal 6(1), 32-38.

Effendi I. 1997. Biologi Perikanan. Yayasan Pustaka Nustama. Jakarta. 159 halaman.

Haliman, R.W., dan D. Adijaya S. 2005. Udang Vannamei, Pembudidayaan dan Prospek Pasar Udang Putih yang Tahan Penyakit. Penebar Swadaya. Jakarta. 74 halaman.

Hari, B., Madhusoodana, K.., Varghese, J.T., Schrama, J.W., Verdegem, M.C.J., 2004. Effects of carbohydrate addition on production in extensive shrimp culture sistems. Aquaculture 241, 179-194.

Hariyadi, B., Haryono, A. dan Untung Susilo. 2005. Evaluasi Efesiensi Pakan dan Efisiensi Protein Pada Ikan Karper Rumput (Ctenopharyngodon idella Val) yang Diberi Pakan dengan Kadar Karbohidrat dan Energi yang Berbeda. Fakultas Biologi Unseod. Purwokerto.

Nunes, A.J.P dan Sabry-Neto. 2011. Growth performance of The White Shrimp,Litopenaeus vannamei,Fedon Practical Diets with Increasing Levels of The Antarctic Krill Meal,Euphausia superba,Reared inClear-versus GreenWater Culture Tanks. Aquaculture Nutrition, 17(2), 511-520.

Purnamasari, I., Purnama, D., Utami, M. A. F. Pertumbuhan udang vaname (Litopenaeus vannamei) di Tambak intensif. Jurnal enggano, 2(1), 58-67. 
Rakhfid, A. Baya, N. Bakri, M, dan Fendi, F. Pertumbuhan dan kelangsungan hidup udang vaname (Litopenaeus vannamei) pada padat tebar berbeda. Jurnal Akuakultur, Pesisir dan Pulau-Pulau Kecil, 1(2), 1-6.

Setya Wardana, Agung., 2012. Teknologi Pegolahan Susu. Surakarta. Fakultas Teknologi Pertanian. Universitas Slamet Riyadi.

Supono, J. Hutabarat, S.B. Prayitno, Y.S. Darmanto. 2014. White Shrimp (Litopenaeus vannamei) Culture using Heterotrophic Aquaculture System on Nursery Phase. International Journal of Waster Resources, 4(2), 1-4.

Yuniasari, D. 2009. Pengaruh Pemberian Bakteri Nitrifikasi dan Denitrifikasi serta Molase dengan $\mathrm{C} / \mathrm{N}$ Rasio Berbeda terhadap Profil Kualitas Air, Kelangsungan Hidup, dan Pertumbuhan Udang Vaname (Litopenaeus vannamei). Skripsi. Fakultas Perikanan dan Ilmu Kelautan. Departemen Budidaya Perairan. Institut Pertanian Bogor. Bogor. 